\title{
A new method to quantify mineral dust and other aerosol species from aircraft platforms using single-particle mass spectrometry
}

Karl D. Froyd et al.

Correspondence to: Karl D. Froyd (karl.froyd@ noaa.gov)

The copyright of individual parts of the supplement might differ from the CC BY 4.0 License. 
Table S1. Calibration solutions used for PALMS sulfate/organic mass calibration

\begin{tabular}{|c|c|c|c|c|c|}
\hline Calibration series & Organic components & Sulfate components & Other components & Particle size range & Particle RH \\
\hline Sulfate/Organic1 & $\begin{array}{l}1: 1 \text { adipic and succinic } \\
\text { acid mixture, } 0-100 \mathrm{wt} \%\end{array}$ & $\begin{array}{l}\text { Ammonium sulfate, } \\
0-100 \mathrm{wt} \%\end{array}$ & & $\mathrm{D}_{\mathrm{a}}<1 \mu \mathrm{m}$, polydisperse & $<20 \%$ \\
\hline Sulfate/Nitrate/Organic1 & $\begin{array}{l}1: 1 \text { adipic and succinic } \\
\text { acid mixture, } 0-75 \mathrm{wt} \%\end{array}$ & $\begin{array}{l}\text { Ammonium sulfate, } \\
19-78 \mathrm{wt} \%\end{array}$ & $\begin{array}{l}\text { Ammonium nitrate, } \\
6-22 \%\end{array}$ & $\mathrm{D}_{\mathrm{a}}<1 \mu \mathrm{m}$, polydisperse & $<20 \%$ \\
\hline Acidic Sulfate/Organic1 & $\begin{array}{l}1: 1 \text { adipic and succinic } \\
\text { acid mixture, } 50 \mathrm{wt} \%\end{array}$ & $\begin{array}{l}\text { Ammonium sulfate, } \\
25 \mathrm{wt} \%\end{array}$ & $\begin{array}{l}\text { Sulfuric acid, } \\
25 \mathrm{wt} \%\end{array}$ & $\mathrm{D}_{\mathrm{a}}<1 \mu \mathrm{m}$, polydisperse & $<20 \%$ \\
\hline Sulfate/Organic2 & $\begin{array}{l}1: 1 \text { sucrose and adipic } \\
\text { acid mixture, } 0-100 \mathrm{wt} \%\end{array}$ & $\begin{array}{l}\text { Ammonium sulfate, } \\
0-100 \mathrm{wt} \%\end{array}$ & & $\mathrm{D}_{\mathrm{a}}<2 \mu \mathrm{m}$, polydisperse & $<40 \%$ \\
\hline $\begin{array}{l}\text { Sulfate/Organic2/K+ } \\
\text { (Biomass burning } \\
\text { surrogates) }\end{array}$ & $\begin{array}{l}1: 1 \text { sucrose and adipic } \\
\text { acid mixture, } 0-99 \text { wt } \%\end{array}$ & $\begin{array}{l}\text { Ammonium sulfate, } \\
0-99 \mathrm{wt} \%\end{array}$ & $\begin{array}{l}\text { Potassium chloride, } \\
\sim 1 \mathrm{wt} \%\end{array}$ & $\mathrm{D}_{\mathrm{a}}<2 \mu \mathrm{m}$, polydisperse & $<40 \%$ \\
\hline
\end{tabular}



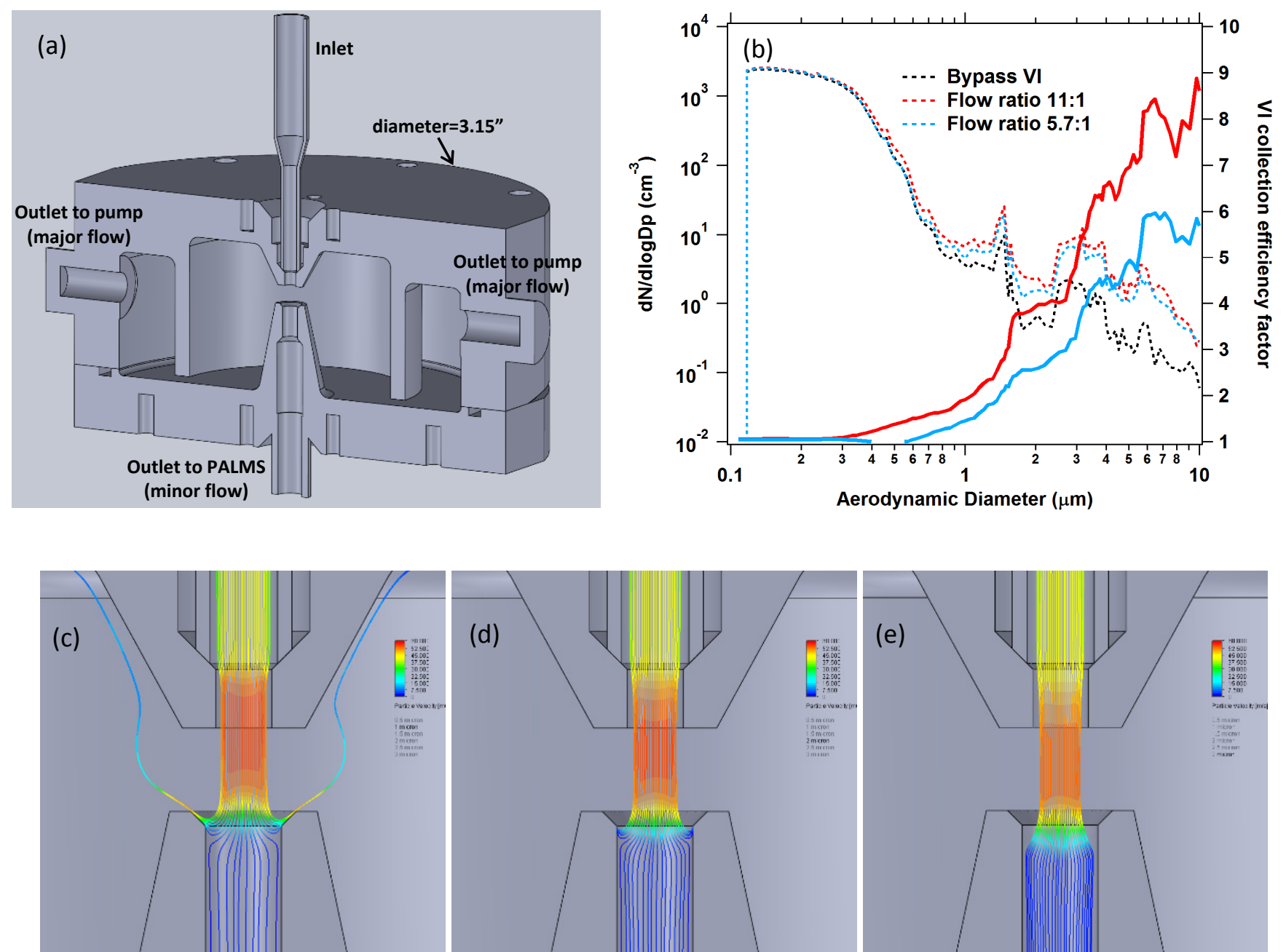

Figure S1. (a) Schematic of the aerosol virtual impactor (VI) used for ATom campaigns. (b) Laboratory characterization using dry ammonium sulfate particles measured by the LAS particle spectrometer at two different total-to-minor flow ratios (dotted lines, left axis). 50\% maximum enhancement (solid lines, right axis) was observed at approximately $\mathrm{D}_{a}(50 \%)=2.0-2.5 \mu \mathrm{m}$. Volume-equivalent diameters were converted to aerodynamic diameters using a density of $1.75 \mathrm{~g} \mathrm{~cm}^{-3}$. Computational fluid dynamics simulations of particle trajectories in the collection region, colored by velocity, for $D_{a}=1.0$ (c), 2.0 (d), and 3.0 (e) $\mu \mathrm{m}$, injected with equidistant radial spacing across the inlet tube. Simulated $\mathrm{D}_{\mathrm{a}}(50 \%)$ is approximately $2.0 \mu \mathrm{m}$, where half of the particles are transmitted to the PALMS instrument and the other half impact the top of the receiving outlet cone. 

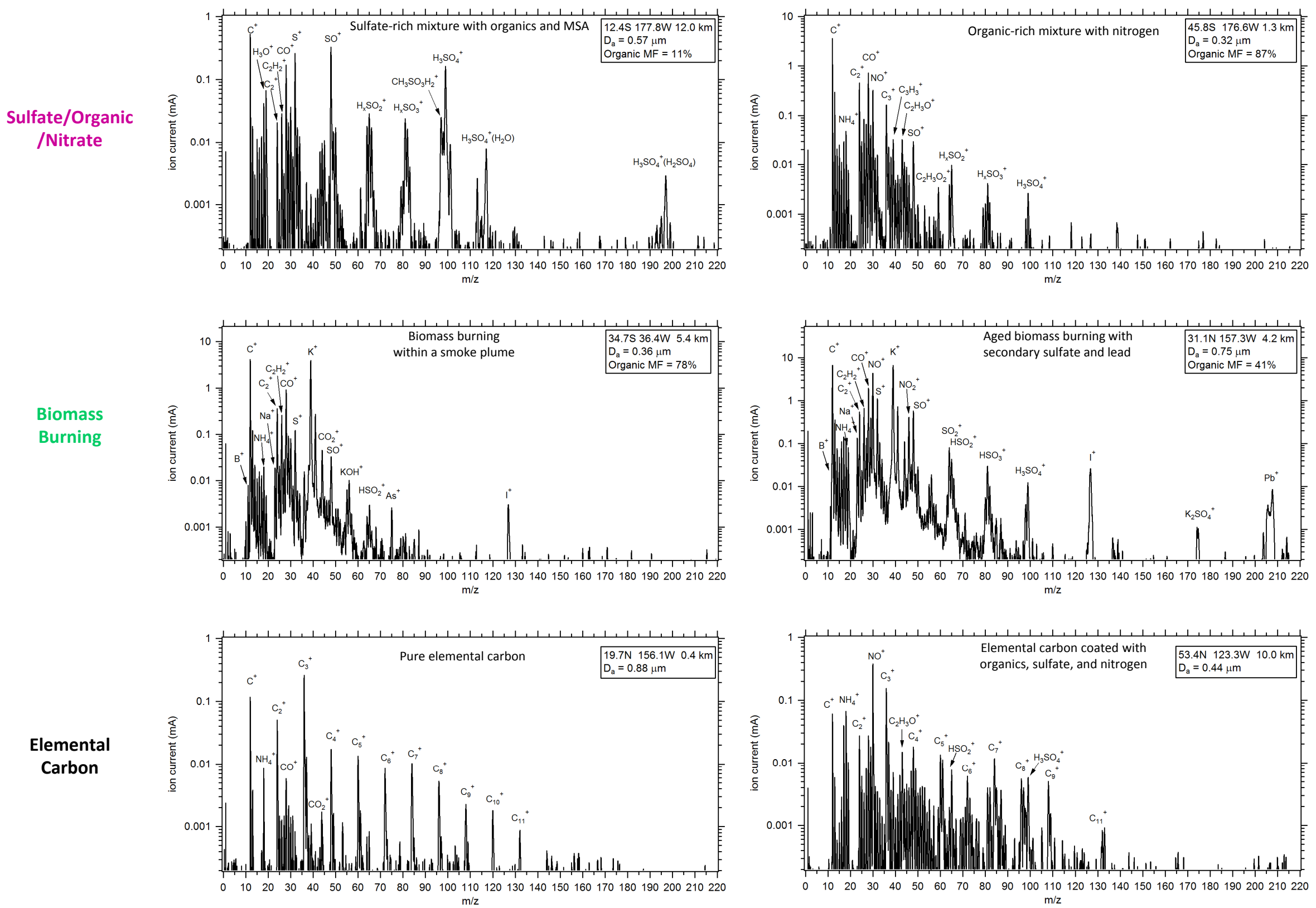


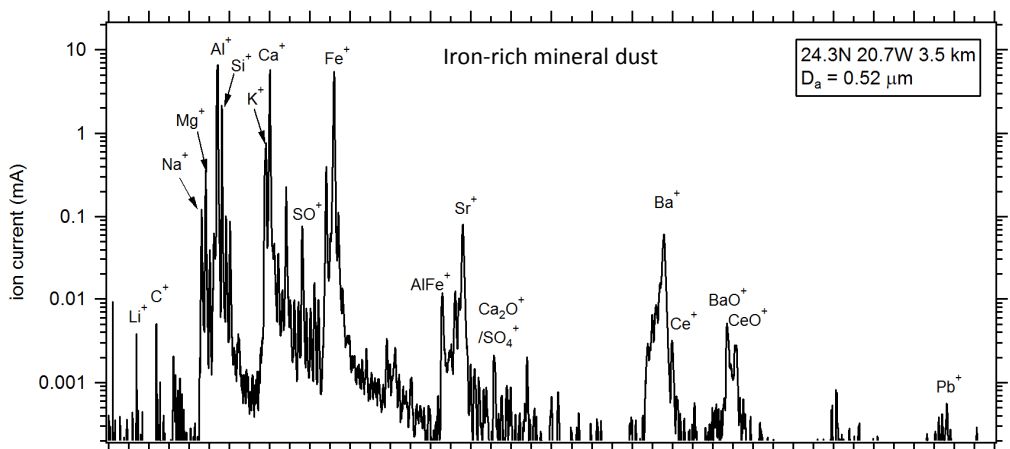

$0 \begin{array}{llllllllll}0 & 10 & 30 & 40 & 50 & 60 & 70 & 80 & 90 & 100110120130140150160170180190200210220\end{array}$
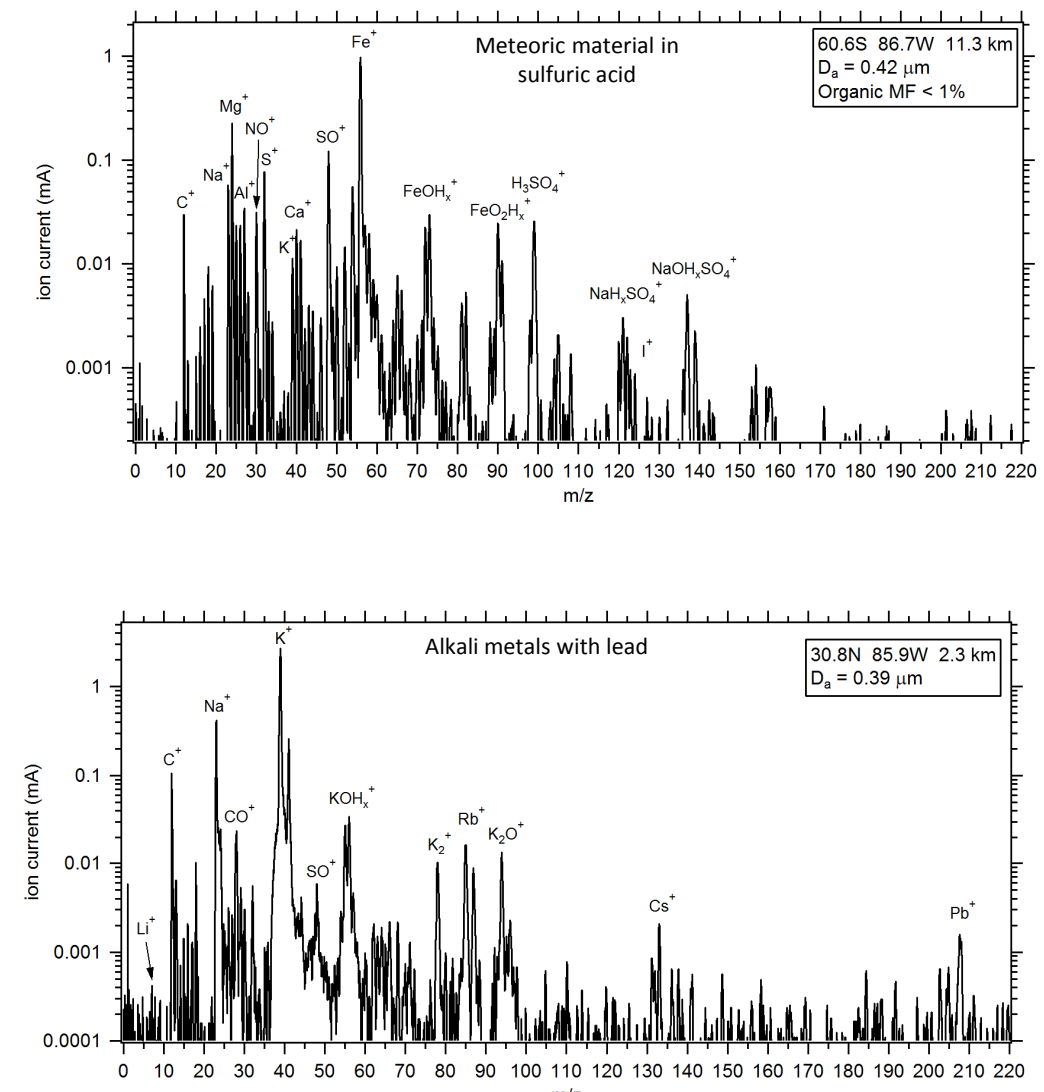
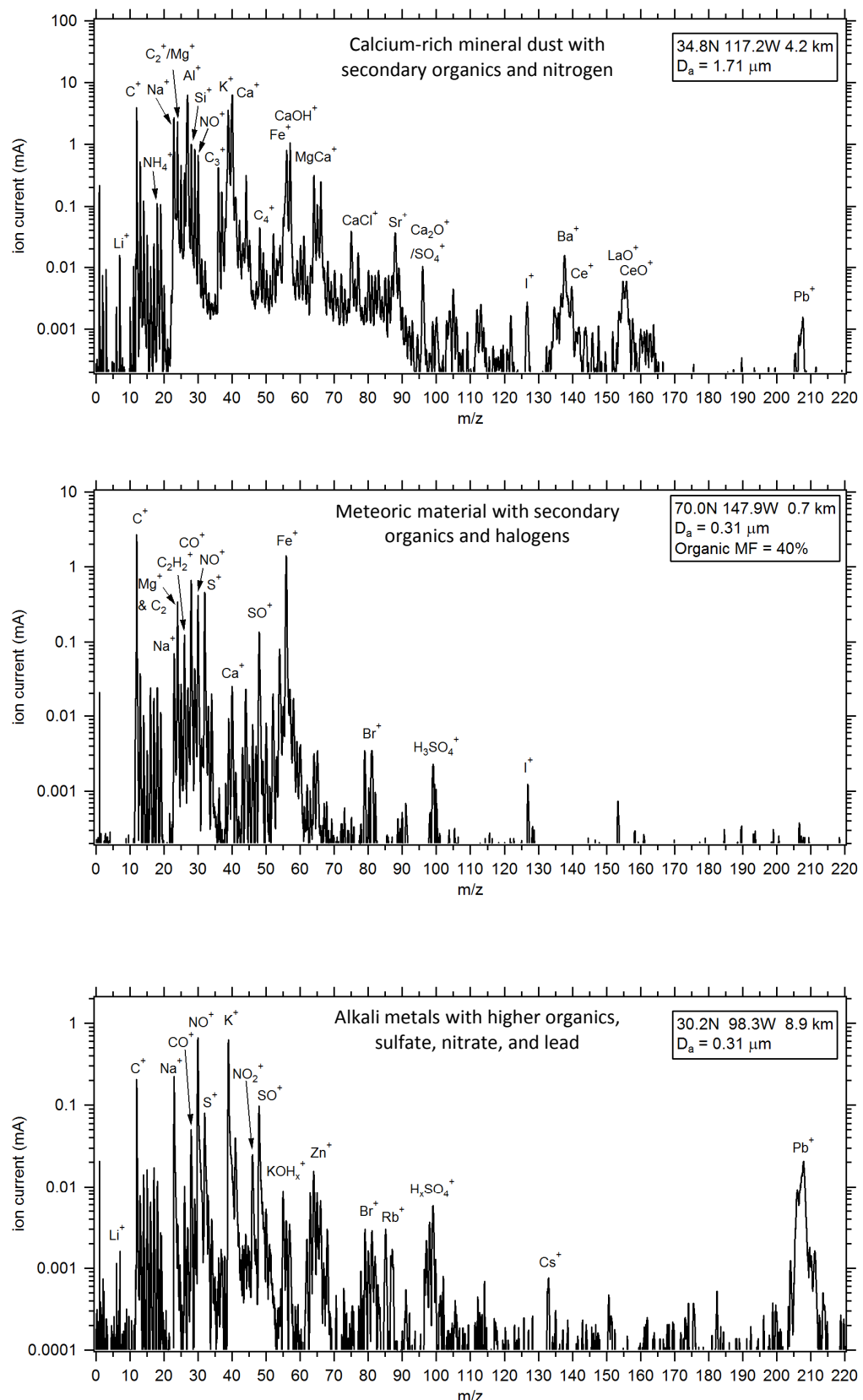

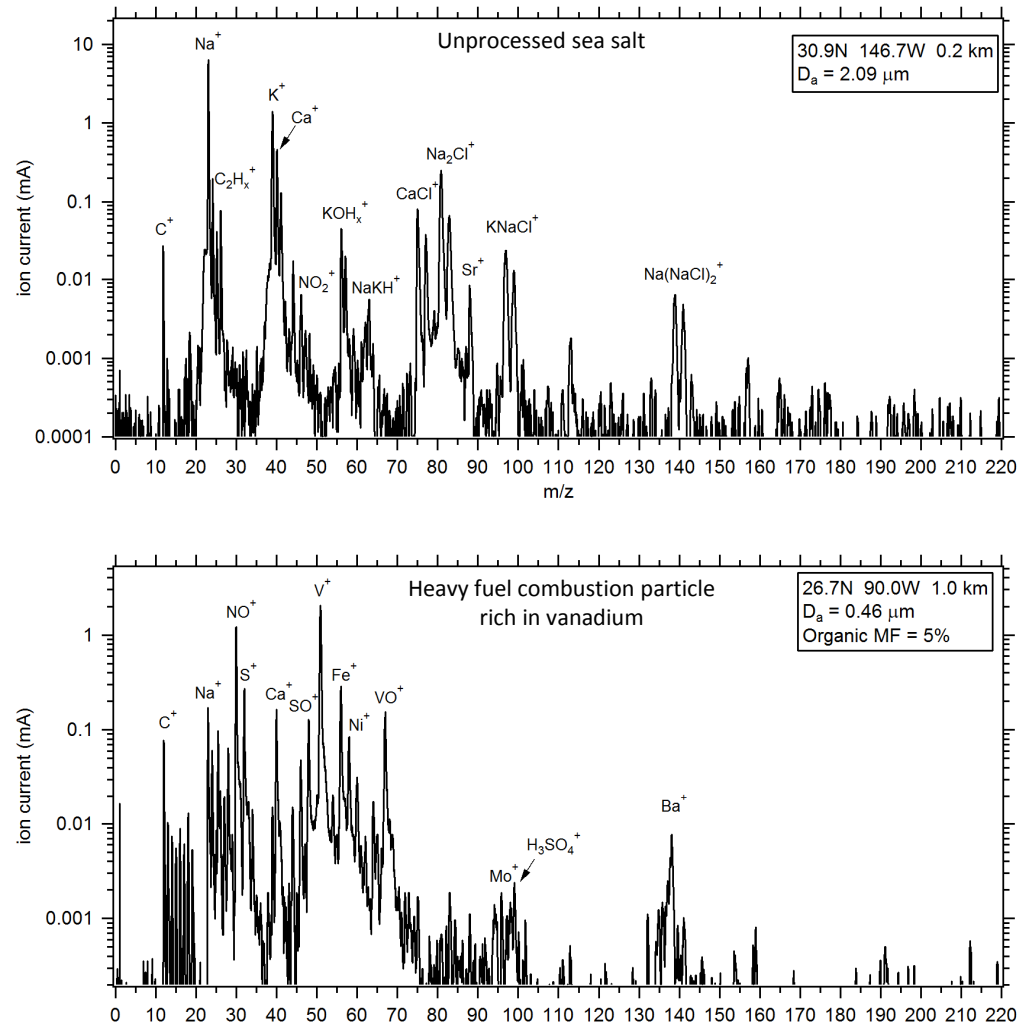

$\mathrm{m} / \mathrm{z}$

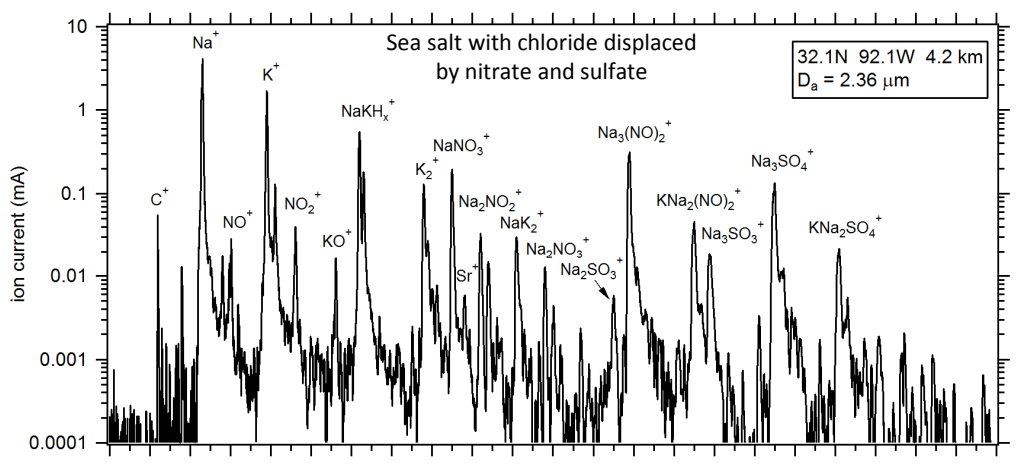

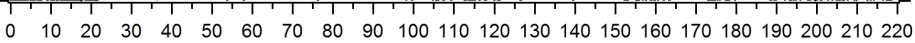

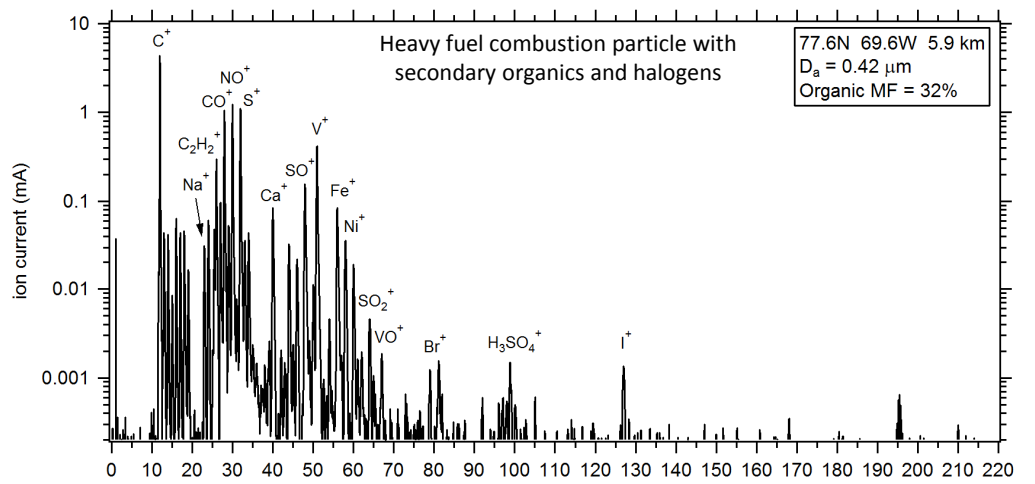

Figure S2. Representative positive spectra of individual particles. Two different spectra are given for each of 8 composition classes. For all but the sulfate/organic/nitrate class, the left column shows relatively pure examples that represent composition near particles sources. Spectra in the right column show the effects of secondary accumulation on aged particles. Organic mass fractions (MF) are calculated from laboratory calibrations of organic and sulfate signals. 

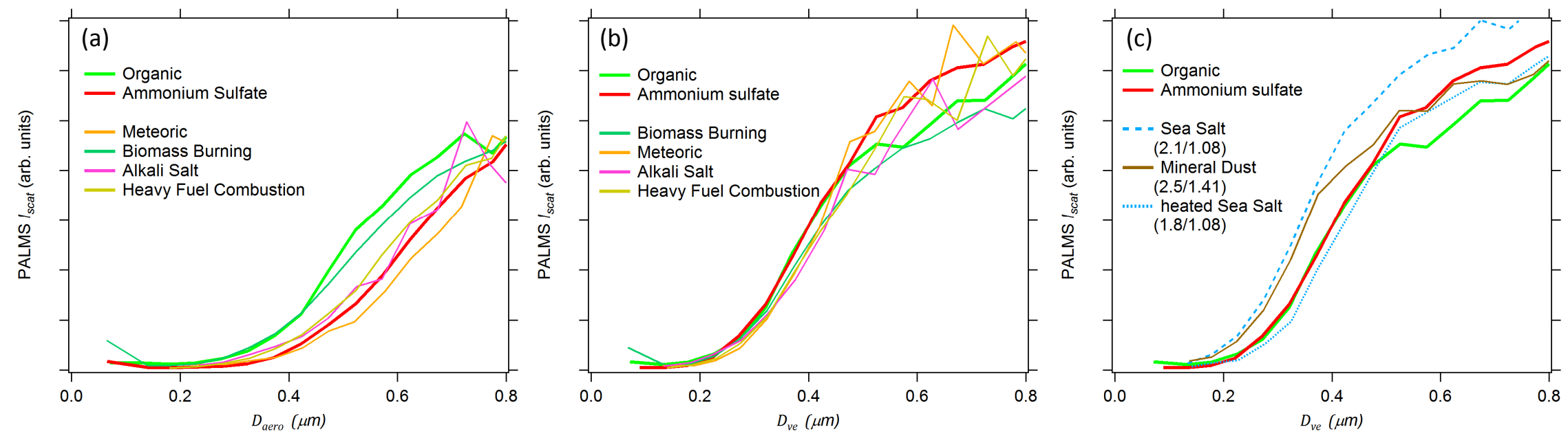

Figure S3. Optical and aerodynamic diameter measurements for additional PALMS particle types from the SEAC4RS campaign. Ammonium sulfate and organic-rich curves are duplicated from Fig 5. Aerodynamic diameters (a) are converted to volume-equivalent diameters (b) using densities and shape factors described in the text. c) Common literature values for sea salt and mineral dust densities $\left(\mathrm{g} \mathrm{cm}^{-3}\right)$ and shape factors (in parentheses, respectively) yield curves that are inconsistent with other particle types. Sea salt particles heated to $300^{\circ} \mathrm{C}$ for $3.3 \mathrm{sec}$ are consistent with prescribed density and shape factor of $1.8 \mathrm{~g} \mathrm{~cm}^{-3}$ and 1.08 , confirming that particles had undergone efflorescence. Note that a density of $2.1 \mathrm{~g} \mathrm{~cm}^{-3}$ and shape factor 1.25, which is a theoretical value for a perfect cubes under vacuum conditions (Dahneke, 1973a,b), gives identical results to the 1.8/1.08 line. This density is consistent with the $1.8 \mathrm{~g} \mathrm{~cm}^{-3}$ value observed by Shinozuka et al. (2004) and suggests that, in absence of non-volatile organic material, about $30 \%$ of heated sea salt particle mass is water. This residual water mass is somewhat higher than the $15-20 \%$ estimated contribution from magnesium hydrates, which would correspond to a particle density of $2.0 \mathrm{~g} \mathrm{~cm}^{-3}$ (Lewis and Schwarz 2004 and therein).

\section{Supplemental References}

Dahneke, B. E.: Slip correction factors for nonspherical bodies - I Introduction and continuum flow, J. Aerosol Sci., 4(2), 139-145, doi:10.1016/0021-8502(73)90065-7,

1973a.

Dahneke, B. E.: Slip correction factors for nonspherical bodies-II free molecule flow, J. Aerosol Sci., 4(2), 147-161, doi:10.1016/0021-8502(73)90066-9, 1973b.

Lewis, R. and Schwartz, E.: Sea Salt Aerosol Production: Mechanisms, Methods, Measurements and Models-A Critical Review, American Geophysical Union,

Washington, D. C., 2004.

Shinozuka, Y., Clarke, A. D., Howell, S. G., Kapustin, V. N. and Huebert, B. J.: Sea-salt vertical profiles over the Southern and tropical Pacific oceans: Microphysics, optical properties, spatial variability, and variations with wind speed, J. Geophys. Res. D Atmos., 109(24), 1-17, doi:10.1029/2004JD004975, 2004. 